\title{
Pengaruh Pengungkapan Corporate Social Responsibility Pada Nilai Perusahaan Dengan Ukuran Perusahaan Sebagai Variabel Moderasi
}

\section{Luh Putri Wedayanti ${ }^{1}$ I Gde Ary Wirajaya ${ }^{2}$}

${ }^{1}$ Fakultas Ekonomi dan Bisnis Universitas Udayana (Unud), Bali - Indonesia email: putriwedayanti07@gmail.com/ Telp: 082144404496

${ }^{2}$ Fakultas Ekonomi dan Bisnis Universitas Udayana (Unud), Bali - Indonesia

\begin{abstract}
ABSTRAK
Penelitian ini bertujuan untuk mengetahui pengaruh ukuran perusahaan dalam memoderasi hubungan pengungkapan CSR pada nilai perusahaan. Penelitian ini mengambil objek pada perusahaan pertambangan dan menggunakan periode selama 3 tahun yaitu dari tahun 20142016. Metode penelitian yang digunakan dalam penelitian ini adalah penelitian asosiatif kausalitas. Jenis data yang digunakan dalam penelitian ini adalah data kuantitatif. Penentuan sampel dalam penelitian ini menggunakan metode nonprobability sampling dengan teknik purposive sampling. Terdapat 21 perusahaan pertambangan yang memenuhi kriteria sebagai sampel. Teknik analisis data yang digunakan adalah Moderated Regression Analysis (MRA). Berdasarkan hasil penelitian, menunjukkan bahwa ukuran perusahaan sebagai variabel moderasi mampu memperkuat pengaruh pengungkapan CSR pada nilai perusahaan. Artinya, semakin besar ukuran perusahaan dan semakin banyak pengungkapan CSR perusahaan maka dapat meningkatkan nilai perusahaan.
\end{abstract}

Kata Kunci: pengungkapan csr, ukuran perusahaan, nilai perusahaan

\begin{abstract}
This study aims to determine the effect of firm size in moderating the CSR disclosure relationship on firm value. This research takes object in mining company and use period for 3 year that is from year 2014-2016. The research method used in this research is associative research causality. The type of data used in this study is quantitative data. Determination of the sample in this study using nonprobability sampling method with purposive sampling technique. There are 21 mining companies that meet the criteria as sample. Data analysis technique used is Moderated Regression Analysis (MRA). Based on the result of research, show that firm size as a moderating variable can strengthen the influence of CSR disclosure on company value. That is, the larger the size of the company and the more CSR corporate disclosure then it can increase the value of the company.

Keywords: csr disclosure, firm size, firm value
\end{abstract}




\section{PENDAHULUAN}

Nilai perusahaan adalah harga yang bersedia dibayar oleh calon pembeli apabila perusahaan tersebut dijual. Semakin tinggi nilai perusahaan, maka semakin besar kemakmuran yang diterima oleh pemilik perusahaan (Wiagustini, 2010:8). Salah satu indikator yang digunakan dalam menilai potensi dari nilai perusahaan yaitu dapat dilihat dari kemampuan perusahaan dalam menghasilkan laba (Puspaningrum, 2017). Perusahaan dengan peningkatan laba yang signifikan akan menunjukkan kinerja perusahaan yang baik dalam mengelola bisnisnya (Inastri, 2017). Hal ini dapat memberi sinyal positif kepada investor, bahwa modal yang telah mereka investasikan akan menghasilkan keuntungan di masa mendatang. Semakin banyak investor yang menanamkan modalnya di suatu perusahaan, maka semakin tinggi pula harga saham dari perusahaan tersebut. Hal ini dapat menyebabkan nilai perusahaan semakin meningkat, karena nilai perusahaan direfleksikan dengan harga saham.

Naik turunnya atau fluktuasi nilai perusahaan menjadi salah satu fenomena yang menarik dalam meneliti nilai perusahaan. Selama kurun waktu 2014-2016, nilai perusahaan pertambangan mengalami fluktuasi. Berikut ini merupakan data nilai perusahaan dari beberapa perusahaan pertambangan. 
Tabel 1.

Nilai Perusahaan Pertambangan yang Terdaftar di Bursa Efek Indonesia Tahun 2014-2016

\begin{tabular}{|c|c|c|c|c|}
\hline \multirow[b]{2}{*}{ NO } & \multirow[b]{2}{*}{ NAMA PERUSAHAAN } & \multicolumn{3}{|c|}{ Nilai Perusahaan (Tobin’s Q) } \\
\hline & & 2014 & 2015 & 2016 \\
\hline 1 & $\begin{array}{c}\text { ANTM } \\
\text { (Aneka Tambang (Persero) Tbk) }\end{array}$ & 0,92 & 0,65 & 1,10 \\
\hline 2 & $\begin{array}{c}\text { CKRA } \\
\text { (Cakra Mineral Tbk) }\end{array}$ & 1,00 & 0,30 & 0,41 \\
\hline 3 & $\begin{array}{c}\text { DKFT } \\
\text { (Central Omega Resourch Tbk) }\end{array}$ & 1,93 & 1,68 & 1,36 \\
\hline 4 & $\begin{array}{c}\text { CITA } \\
\text { (Cita Mineral Investindo Tbk) }\end{array}$ & 1,55 & 1,67 & 1,76 \\
\hline 5 & $\begin{array}{c}\text { CTTH } \\
\text { (Citatah Tbk) }\end{array}$ & 1,01 & 0,64 & 0,65 \\
\hline 6 & $\begin{array}{c}\text { ELSA } \\
\text { (Elnusa Tbk) }\end{array}$ & 1,57 & 0,81 & 1,04 \\
\hline 7 & $\begin{array}{c}\text { MITI } \\
\text { (Mitra Investindo Tbk) }\end{array}$ & 0,90 & 1,19 & 0,96 \\
\hline 8 & $\begin{array}{c}\text { PTBA } \\
\text { (PT Bukit Asam (Persero) Tbk) }\end{array}$ & 2,36 & 1,07 & 1,98 \\
\hline 9 & $\begin{array}{c}\text { RUIS } \\
\text { (Radiant Utama Interinsco Tbk) }\end{array}$ & 0,89 & 0,84 & 0,82 \\
\hline 10 & $\begin{array}{c}\text { ARTI } \\
\text { (Ratu Prabu Energy Tbk) }\end{array}$ & 0,54 & 0,86 & 0,49 \\
\hline
\end{tabular}

Sumber:Data diolah, 2018

Tabel 1 menunjukkan bahwa nilai perusahaan pertambangan berdasarkan perhitungan Tobins's Q selama kurun waktu 3 tahun yang mengalami fluktuasi. Aneka Tambang (Persero) Tbk, sempat mengalami penurunan nilai perusahaan pada tahun 2015, namun pada tahun 2016 mengalami peningkatan yaitu sebesar dari 0,65 menjadi 1,10. Hal yang sama juga dirasakan pada PT Bukit Asam (Persero) Tbk, Citatah Tbk, Elnusa Tbk, dan Cakra Mineral Tbk. Sedangkan pada perusahaan tambang Central Omega Resourch Tbk, Mitra Investindo Tbk, dan Ratu Prabu Energy Tbk mengalami hal yang sebaliknya, yaitu peningkatan nilai perusahaan pada tahun 2015, kemudian pada tahun 2016 mengalami penurunan. Selain itu, Cita Mineral Investindo Tbk mengalami peningkatan nilai perusahaan 
selama berturut-turut, dan Radiant Utama Interinsco Tbk, sebaliknya mengalami penurunan nilai perusahaan secara berturut-turut dalam kurun waktu 2014-2016. Hal ini mengindikasikan bahwa terdapat beberapa faktor yang mengakibatkan nilai perusahaan menjadi berfluktuasi.

Pada umumnya, tujuan jangka panjang suatu perusahaan adalah untuk meningkatkan keuntungan sehingga nilai perusahaan pun akan meningkat. Dalam meningkatkan keuntungan, seringkali perusahaan melupakan pentingnya lingkungan, sehingga banyak terjadinya kasus pengeksploitasian sumber daya alam. Eksploitasi sumber daya alam dapat berdampak pada kerusakan lingkungan, dan dalam jangka panjang dapat mengganggu keseimbangan kehidupan sosial manusia. Oleh sebab itu, selain memperhatikan faktor finansial, perusahan juga harus memperhatikan faktor non finansialnya. Tujuannya adalah untuk memberikan perhatian terhadap lingkungan, maupun masyarakat yang tinggal berdekatan dengan perusahaan tersebut dalam melakukan kegiatan operasionalnya. Faktor non finansial yang dimaksudkan adalah melakukan program Corporate Social Responsibility (CSR) atau tanggung jawab sosial perusahaan. CSR merupakan salah satu faktor non finansial yang perlu dipertimbangan oleh manajemen dalam meningkatkan nilai perusahaan (Umbara \& Suryanawa, 2014). Pengungkapan CSR pada saat ini bukan dianggap sebagai biaya, melainkan sudah menjadi aset perusahaan. Pengungkapan CSR bisa mempengaruh nilai perusahaan dapat dilihat dari aset perusahaan yang semakin bertambah. 
CSR adalah tanggung jawab sosial suatu perusahaan terhadap para stakeholders, khususnya kepada masyarakat yang tinggal berdekatan dengan lokasi suatu perusahaan. Perusahaan tidak hanya berperan dalam mengoptimalkan kinerja laba perusahaan saja, melainkan juga ikut serta dalam memperhatikan lingkungan masyarakat (Bulan \& Astika, 2014). Perusahaan yang melakukan pengungkapan CSR akan mendapatkan respon yang positif dari para pelaku pasar, karena perusahaan tersebut dianggap transparan dalam mengungkapkan informasi (Puspaningrum, 2017). Program CSR juga dapat meningkatkan citra perusahaan, sehingga nilai perusahaan akan semakin baik apabila citra perusahaan baik pula. Semakin luas perusahaan mengungkapkan item pengungkapan sosialnya, dan semakin bagus kualitas pengungkapannya, maka semakin tinggi pula nilai perusahaan tersebut (Prayogo, 2013).

Teori sinyal mengemukakan tentang bagaimana seharusnya sebuah perusahaan memberikan sinyal kepada pengguna laporan keuangan (Silalahi \& Ardini, 2017).Berdasarkan hasil penelitian terdahulu mengenai hubungan pengungkapan CSRterhadap nilai perusahaan, terdapat banyak ketidaksamaan hasil. Penelitian Primady \& Wahyudi (2015), Dewi \& Monalisa (2016), serta Ilmi, Kustono, \& Sayekti (2017) menunjukkan tidak adanya pengaruh CSR terhadap nilai perusahaan. Hal ini dikarenakan pada saat perusahaan mengungkapkan tanggungjawab sosialnya yang bertujuan untuk memberikan isyarat kepada pasar, belum ditanggapi dengan baik oleh pasar, sehingga tidak berdampak pada kenaikan nilai perusahaan. Hasil yang bertentangan ditemukan pada penelitian Medyawati \& Yunanto (2017), Nguyen et al. (2015), serta Mukhtaruddin, 
Relasari, \& Felmania (2014), menemukan bahwa pengungkapan CSRberpengaruh terhadap nilai perusahaan. Hal ini dikarenakan pengungkapan CSR yang dilakukan oleh perusahaan dapat memberikan citra positif terhadap perusahaan tersebut. Hasil yang sama juga ditemukan pada penelitian Susanti, Marietza, \& Indriani (2012) dan Putri \& Suprasto (2016) menemukan bahwa pengungkapan CSRberpengaruh positif terhadap nilai perusahaan. Semakin luas sebuah perusahaan dalam mengungkapkan tanggung jawab sosialnya, maka nilai perusahaan juga akan semakin meningkat.

Perusahaan yang mengungkapkan kepedulian terhadap lingkungan, dalam jangka panjang dapat terhindar dari kerugian yang sangat besar akibat adanya tuntutan masyarakat (Subiantoro \& Mildawati, 2015). Salah satu contohnya yaitu pada kasus PT Lapindo Brantas. Inc di Kabupaten Sidoarjo, Jawa Timur, merupakan perusahaan pertambangan gas bumi, yang memicu terjadinya semburan lumpur dari perut bumi. Kerugian yang ditimbulkan akibat dari semburan lumpur tersebut diantaranya kerugian ekonomi, industri dan infrastruktur. Kerugian ekonomi masyarakat antara lain hilangnya aset yang berupa lahan pertanian dan rumah. Kerugian industri yaitu hilangnya aset pabrik yang terendam lumpur dan hilangnya potensi pendapatan pabrik. Kerugian infrastruktur meliputi rusaknya jalan, jaringan listrik dan sarana publik lainnya, mulai dari sekolah hingga kantor desa (Listiyorini, 2007).

Selain CSR, ukuran perusahaan merupakan variabel penduga yang digunakan dalam menjelaskan pengungkapan dalam laporan tahunan perusahaan (Putri, Sudarma, \& Purnomosidhi, 2016). Ukuran perusahaan merupakan suatu 
perbandingan yang digunakan untuk melihat besar kecilnya sebuah entitas. Skala ukuran perusahaan dapat mempengaruhi luas pengungkapan informasi dalam laporan keuangan (Subiantoro \& Mildawati, 2015). Secara umum, perusahaan besar akan lebih banyak memerlukan pengungkapan informasi daripada perusahaan kecil. Semakin besar ukuran perusahaan, maka aktivitas yang dilakukan juga lebih banyak sehingga tanggung jawab dari perusahaan tersebut tidak hanya terhadap pemegang saham saja, tetapi juga terhadap masyarakat dan lingkungan sekitar perusahaan (Kusumawardani \& Sudana, 2017).

Penelitian ini mengacu pada peneliti Umbara \& Suryanawa (2014), yang meneliti tentang Pengaruh Pengungkapan Tanggung Jawab Sosial Pada Nilai Perusahaan. Perbedaan penelitian ini dengan penelitian sebelumnya adalah ditambahkannya ukuran perusahaan sebagai variabel moderasi. Ukuran perusahaan digunakan sebagai variabel moderasi karena ukuran perusahaan berpengaruh terhadap luas pengungkapan informasi. Perusahaan dengan aset yang besar memiliki tanggungjawab yang luas, bukan hanya dengan pemegang sahamnya saja melainkan juga dengan stakeholder lainnya seperti masyarakat sekitar dan pemerintah. Perbedaan lainnya antara penelitian ini dengan penelitian sebelumnya yaitu pada pengukuran standar yang digunakan untuk mengungkapkan CSR. Penelitian sebelumnya menggunakan standar Global Reporting Initiative (GRI) G3.1. Penelitian ini menggunakan standar Global Reporting Initiative (GRI) G4. Standar Global Reporting Initiative (GRI) G4, merupakan acuan wajib diterapkan untuk laporan yang diterbitkan setelah tanggal 31 Desember 2015. Selain itu penelitian ini berfokus pada perusahaan yang 
terkategori sebagai perusahaan high profile, dan mengambil objek pada Perusahaan Pertambangan yang terdaftar di Bursa Efek Indonesia. Penelitian ini menggunakan periode selama 3 tahun yaitu dari tahun 2014-2016.

Penelitian ini dilakukan berdasarkan ketidakkonsistenan dari hasil penelitian-penelitian sebelumnya. CSR dipilih karena memberikan tanggungjawab besar terhadap perusahaan yang memanfaatan sumber daya alam dalam kegiatan operasinya, dimana pemanfaatan tersebut dapat berdampak langsung pada lingkungan. Indonesia merupakan salah satu negara dengan kekayaan sumber daya alam yang melimpah, salah satunya adalah bahan tambang.

Tujuan penelitian yang dapat dirumuskan adalah untuk mengetahui dan mendapatkan bukti empiris bahwa ukuran perusahaan mampu memoderasi pengaruh Corporate Social Responsibility (CSR) terhadap nilai perusahaan. Penelitian ini dapat menjadi referensi serta menambah wawasan dan bukti empiris tentang studi yang membahas pengaruh ukuran perusahaan dalam memoderasi hubungan CSR pada nilai perusahaan. Hasil dari penelitian ini dapat memberikan pemahaman mengenai realita teori sinyal dan teori legitimasi, dimana perusahaan akan memberikan sinyal kepada pihak luar, baik investor maupun masyarakat berupa informasi yang menujukkan bahwa perusahaan memiliki nilai yang baik dibandingkan dengan perusahaan lain.

Dalam penelitian ini dapat dibuktikan teori mana yang cenderung terjadi pada perusahaan pertambangan yang terdaftar di Bursa Efek Indonesia. Hal ini dapat memberikan kontribusi dalam kajian empiris dan dapat dijadikan perbandingan, pengembangan, serta penyempurnaan dari penelitian yang telah 
dilakukan sebelumnya. Penelitian ini disajikan untuk memberikan masukan dan bahan pertimbangan dalam pengambilan keputusan yang berkaitan dengan nilai perusahaan. Penelitian ini juga bisa memberikan referensi bagi perusahaan yang memerlukan informasi dari penelitian ini untuk dijadikan sebagai dasar dalam melakukan pengambilan keputusan.

Berdasarkan landasan teori dan kajian empiris penelitian sebelumnya, maka peneliti merumuskan kerangka konsep penelitian seperti pada Gambar 1 sebagai berikut.

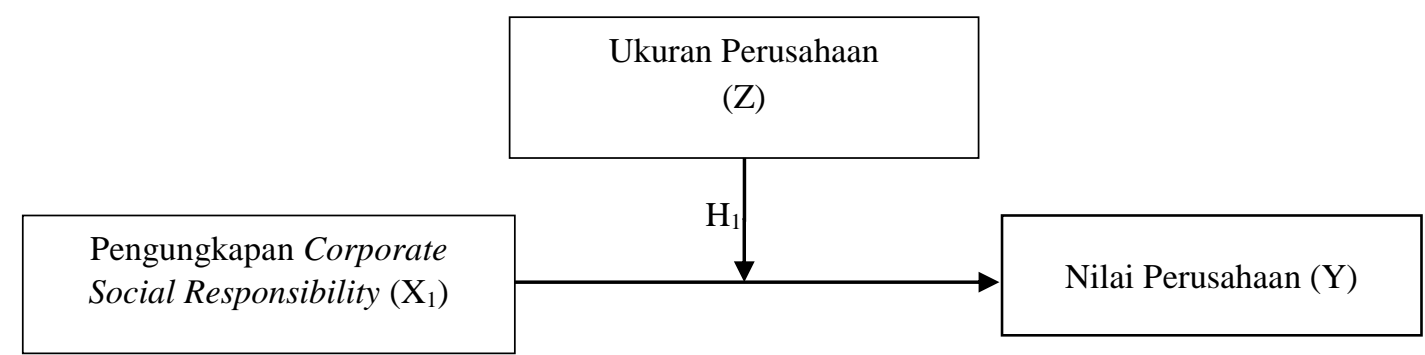

\section{Gambar 1. Kerangka Konseptual Penelitian}

Pada penelitian ini tidak menguji pengaruh langsung dari pengungkapan CSR pada nilai perusahaan. Hal ini dikarenakan pada penelitian-penelitian terdahulu banyak terdapat hasil penelitian yang menyatakan bahwa pengungkapan CSR tidak berpengaruh pada nilai perusahaan. Oleh sebab itu, penelitian ini lebih memfokuskan pada efek moderasi yaitu ukuran perusahaan sebagai variabel lain dalam hubungan pengungkapan CSR pada nilai perusahaan.

Ukuran perusahaan diartikan sebagai besar kecilnya usaha dari suatu perusahaan. Dengan demikian ukuran perusahaan merupakan sesuatu yang dapat mengukur atau menentukan nilai dari besar kecilnya suatu perusahaan. Perusahaan besar memiliki aktiva yang besar yang dapat menjamin dalam sumber 
pendanaan, sehingga ukuran perusahaan akan berpengaruh terhadap akses perusahaan untuk memperoleh sumber pendanaan (Silalahi \& Ardini, 2017). Ukuran perusahaan besar akan membuat harga saham perusahaan berada pada posisi yang kuat, sehingga akan menguatkan harga saham di pasar modal (Pratama, 2014).

Teori sinyal menyatakan bahwa pengungkapan CSRsecara luas, dapat memberikan sinyal positif terhadap investor, sehingga dapat meningkatkan nilai perusahaan. Berdasarkan teori legitimasi, setiap perusahaan pada dasarnya harus memberikan manfaatnya kepada masyarakat, yang dapat dilakukan dengan cara melaksanakan program CSR kepada masyarakat dan lingkungan dimana perusahaan tersebut beroperasi, sehingga perusahaan akan mendapatkan umpan balik yaitu berupa legitimasi dari masyarakat. Oleh sebab itu, perusahaan dengan ukuran yang besar akan mengungkapkan informasi tanggung jawab sosialnya lebih luas untuk memberikan sinyal positif terhadap investor dan mendapatkan legitimasi dari masyarakat, karena perusahaan besar melakukan aktivitasnya lebih banyak sehingga akan berdampak lebih besar terhadap lingkungan (Yuliawati \& Sukirman, 2015).

Hasil penelitian yang berlawanan ditemukan pada penelitian Setiadharma \& Machali (2017) dan Anggraini (2006), yang menyatakan bahwa ukuran perusahaan tidak berpengaruh terhadap pengungkapan tanggungjawab sosial perusahaan, hal ini dikarenakan perusahaan yang termasuk dalam industri low profile, akan memberikan informasi sosial lebih sedikit dibandingkan dengan perusahaan high profile. Penelitian ini bertentangan dengan hasil penelitian Putri 
et al. (2016) yang membuktikan bahwa ukuran perusahaan mampu memoderasi pengaruh CSR tehadap nilai perusahaan, yang artinya pengungkapan CSRakan meningkatkan nilai perusahaan, apabila dikuatkan oleh ukuran perusahaan. Hal tersebut karena ukuran perusahaan merupakan salah satu variabel yang paling banyak digunakan untuk menjelaskan pengungkapan sosial yang dibuat oleh perusahaan pada laporan tahunannya. Secara umum, perusahaan besar lebih banyak mengungkapkan informasinya daripada perusahaan kecil, dan perusahaan besar lebih banyak menghadapi resiko politis. Oleh karena itu, untuk mengurangi biaya politis tersebut diperlukannya pengungkapan sosial yang luas (Hasibuan, 2001). Hasil penelitian yang sama juga didukung oleh penelitian Dewi (2015) dan Puspaningrum (2017), yang menemukan bahwa ukuran perusahaan dapat meningkatkan pengaruh CSR terhadap nilai perusahaan.

Ukuran perusahaan dapat memoderasi pengaruh pengungkapan CSR terhadap nilai perusahaan. Perusahaan besar akan cenderung mengungkapkan kinerja perusahaan secara tidak terbatas pada laporan keuangan, akan tetapi juga akan mengungkapkan informasi sosialnya agar terhindar dari biaya yang timbul apabila perusahaan tidak melakukan kegiatan pertanggung jawaban sosialnya. Perusahaan besar juga akan mengungkapkan informasi CSR lebih luas, sehingga image perusahaan akan semakin baik dan nantinya akan berpengaruh terhadap peningkatan nilai perusahaan. Berdasarkan kajian teori dan empiris, maka dapat diasumsikan hipotesis sebagai berikut:

$\mathrm{H}_{1}$ : Ukuran perusahaan memperkuat pengaruh pengungkapan CSR pada nilai perusahaan. 


\section{METODE PENELITIAN}

Penelitian ini dilakukan pada perusahaan pertambangan yang terdaftar di Bursa Efek Indonesia (BEI). Penelitian ini mengamati laporan tahunan perusahaan pertambangan periode 2014-2016 dengan mengakses situs www.idx.co.id.Objek penelitian ini adalah nilai perusahaan, pengungkapanCSR, dengan ukuran perusahaan sebagai variabel pemoderasi pada perusahaan pertambangan yang terdaftar di Bursa Efek Indonesia (BEI) yang dapat dilihat dari annual report perusahaan.

Nilai perusahaan adalah harga yang bersedia dibayar oleh calon pembeli apabila perusahaan tersebut dijual. Nilai perusahaan merupakan nilai yang menggambarkan tingkat kesejahteraan pemegang saham (Sholekah \& Venusita, 2014). Semakin tinggi harga saham, maka semakin tinggi tingkat kesejahteraan yang dirasakan oleh pemegang saham. Dalam meneliti nilai perusahaan, salah satu alternatif yang dapat digunakan adalah dengan rasio Tobins ' $Q$. Rasio Tobins' $Q$ dinilai dapat memberikan informasi terbaik, hal ini dikarenakan rasio ini memuat semua unsur hutang dan modal saham perusahaan, termasuk juga seluruh aset perusahaan. Rasio Tobins' $Q$ dihitung dengan menggunakan rumus sebagai berikut:

Tobin's $\mathrm{Q}=\frac{\text { MVE+DEBT }}{\text { TA }}$

Keterangan:

Tobin's Q = Nilai perusahaan

MVE = Nilai pasar ekuitas

DEBT $=$ Total kewajiban

TA = Nilai buku dari total aktiva 
Corporate Social Responsibility (CSR) merupakan media komunikasi perusahaan dengan masyarakat tentang aktivitas yang dilakukan perusahaan dan berhubungan dengan tanggung jawab sosial perusahaan (Mukhtaruddin et al., 2014). Dalam penelitian ini, pengungkapan CSR diukur dengan Corporate Social Responsibility Index (CSRI) berdasarkan indikator Global Reporting Initiatives (GRI) G4. Adapun rumus penghitungan pengungkapan CSR:

$\mathrm{CSRI}_{\mathrm{j}}=\frac{\boldsymbol{\Sigma} \boldsymbol{x} \boldsymbol{i} \boldsymbol{j}}{\boldsymbol{N} \boldsymbol{j}}$

Keterangan :

CSRIj : Corporate Social Responsibility Disclosure Index perusahaan

$\Sigma X i j \quad:$ Jumlah pengungkapan CSR perusahaan

$\mathrm{Nij} \quad$ : jumlah item yang ditetapkan GRI untuk perusahaan

Ukuran perusahaan adalah suatu perbandingan besar atau kecilnya perusahaan yang dapat diklasifikasikan dengan mengukur total aset yang similiki oleh perusahaan, total penjualan, jumlah penjualan, dan rata-rata tingkat penjualan (Prasetyorini, 2013). Rumus yang digunakan untuk menilai ukuran perusahaan sebagai berikut :

$$
\text { Size }=\log (\text { Total Aset })
$$

Populasi dalam penelitian ini yaitu seluruh perusahaan pertambangan yang terdaftar di Bursa Efek Indonesia (BEI) tahun 2014-2016 dengan teknik purposive sampling. Penelitian ini dilakukan uji asumsi klasik terlebih dahulu kemudian dilakukan teknik analisis data. Teknik analisis data dalam penelitian ini menggunakan uji Moderate Regression Analysis (MRA). Uji MRA merupakan suatu uji yang digunakan untuk mengetahui hubungan antara variabel pengungkapan CSR, ukuran perusahaan, dan nilai perusahaan. Adapun model 
rumus persamaan Moderating Regression Analysis (MRA) yang digunakan dalam penelitian ini adalah sebagai berikut:

$Y=\alpha+\beta_{1} X_{1}+\beta_{2} Z+\beta_{3} X_{1} Z+e$.

Keterangan:

$\mathrm{Y}=$ Nilai Perusahaan

$\alpha \quad=$ Konstanta

$\beta=$ Koefisien regresi

$\mathrm{e} \quad=$ Standar error

$\mathrm{X}_{1} \quad=$ Corporate Social Responsibility

$\mathrm{Z} \quad=$ Ukuran Perusahaan

$\mathrm{X}_{1} \mathrm{Z}=$ Interaksi Corporate Social Responsibility dengan Ukuran Perusahaan

\section{HASIL DAN PEMBAHASAN}

Lokasi penelitian ini dilakukan di perusahaan pertambangan yang terdaftar di Bursa Efek Indonesia dengan memperoleh data melalui alamat website BEI (www.idx.co.id). Sektor pertambangan dipilih karena sektor pertambangan merupakan salah satu jenis perusahaan yang aktivitas operasinya berkaitan langsung dengan alam, sehingga nilai perusahaannya sangat dipengaruhi oleh pandangan publik. Fenomena yang terjadi pada perusahaan pertambangan yaitu pada setiap kegiatan penambangan yang dilakukan perusahaan akan berpotensi memberikan dampak yang negatif terhadap alam atau lingkungan dimana perusahaan tersebut melakukan aktivitas operasinya. Dampak negatif dari aktivitas penambangan tersebut dapat mempengaruhi pandangan publik terhadap perusahaan, sehingga pada dasarnya akan berpengaruh terhadap nilai perusahaan itu sendiri.Kriteria pemilihan sampel penelitian ini disajikan pada Tabel 2 berikut. 
Tabel 2.

Proses dan Hasil Seleksi Sampel berdasarkan Kriteria

\begin{tabular}{|c|c|c|c|}
\hline No & $\begin{array}{l}\text { Keterangan } \\
\text { Populasi: }\end{array}$ & Jumlah & Akumulasi \\
\hline & $\begin{array}{l}\text { Perusahaan Pertambangan di Indonesia yang terdaftar di } \\
\text { Bursa Efek Indonesia tahun 2014-2016 } \\
\text { Kriteria: }\end{array}$ & (41) & (123) \\
\hline 1 & $\begin{array}{l}\text { Perusahaan Pertambangan yang tidak menerbitkan laporan } \\
\text { tahunan secara berturut-turut selama tahun penelitian } \\
2014-2016\end{array}$ & (12) & (36) \\
\hline 2 & $\begin{array}{l}\text { Perusahaan tidak menyediakan informasi lengkap tentang } \\
\text { nilai perusahaan dan ukuran perusahaan selama tahun } \\
\text { penelitian } 2014-2016 \text {. }\end{array}$ & (0) & (0) \\
\hline & $\begin{array}{l}\text { Data Outlier: } \\
\text { Dikeluarkan agar data menjadi normal }\end{array}$ & (8) & (24) \\
\hline \multicolumn{2}{|r|}{$\begin{array}{l}\text { Jumlah observasi yang memenuhi kriteria selama periode } \\
\text { penelitian (2014-2016) }\end{array}$} & 21 & 63 \\
\hline
\end{tabular}

Sumber: Data diolah, 2018

Adanya data outlier dalam penelitian ini disebabkan karena total pengungkapan corporate social responsibility yang dilakukan perusahaan berbeda-beda. Perbedaan yang cukup extreme ini menyebabkan data penelitian menjadi tidak normal, sehinggaharus dilakukan penghilangan data-data extereme tersebut agar model yang diuji sesuai dengan kriteria.

Statistik deskriptif digunakan untuk memberikan informasi mengenai karakteristik variabel-variabel penelitian, yaitu jumlah sampel, nilai rata-rata (Mean), nilai minimum dan maksimum, serta standar deviasi pada variabelvariabel yang diteliti, yaitu Pengungkapan CSR, Ukuran Perusahaan, dan Nilai Perusahaan. Hasil Statistik deskriptif dapat dilihat pada Tabel 3 sebagai berikut: 
Tabel 3.

Statistik Deskriptif Variabel Penelitian

\begin{tabular}{cccccc}
\hline Variabel & N & Min. & Max. & Mean & $\begin{array}{c}\text { Std. } \\
\text { Deviation }\end{array}$ \\
\hline Nilai Perusahaan $(\mathrm{Y})$ & 63 & 0,3011 & 2,3591 & 0,9355 & 0,3418 \\
Pengungkapan CSR $\left(\mathrm{X}_{1}\right)$ & 63 & 0,0549 & 0,6044 & 0,2005 & 0,1189 \\
Ukuran Perusahaan $(\mathrm{Z})$ & 63 & 11,1978 & 15,1576 & 12,5965 & 0,6869 \\
Interaksi $\left(\mathrm{X}_{1} \mathrm{Z}\right)$ & 63 & 0,7158 & 7,8450 & 2,5462 & 1,5729 \\
\hline
\end{tabular}

Sumber: Data diolah, 2018

Tobin's Q merupakan proksi dari variabel nilai perusahaan yang diukur dengan perbandingan antara nilai pasar perusahaan dan nilai pengganti aktiva perusahaan. Berdasarkan hasil uji statistik deskriptif, diperoleh nilai minimum Tobin's Q sebesar 0,3011 dengan nilai maksimum sebesar 2,3591 dan nilai ratarata sebesar 0,9355. Hal ini menunjukkan bahwa rata-rata perusahaan yang dijadikan sampel memiliki nilai yang positif.

Corporate Social Responsibility Indeks (CSRI) merupakan proksi dari variabel pengungkapan CSRyang diukurdengan perbandingan total pengungkapan CSRyang dilakukan perusahaan sampel dengan standar pengungkapan CSR yang ditetapkan oleh global reporting initiative (GRI). Berdasarkan hasil uji statistik deskriptif, diperoleh nilai minimum untuk pengungkapan corporate social responsibility sebesar 0,0549 dengan nilai maksimum sebesar 0,6044. Rata-rata nilai pengungkapan CSR sebesar 0,2005 menunjukkan bahwa pengungkapan CSR yang dilakukan oleh perusahaan publik di Indonesia masih tergolong rendah.

Total aset merupakan proksi variabel ukuran perusahaan, yang diukur dengan cara menghitung log dari total aset perusahaan. Berdasarkan hasil uji 
statistik deskriptif, diperoleh nilai minimum ukuran perusahaan sebesar 11,1978 dengan nilai maksimum sebesar 15,1576 . Standar deviasi dari ukuran perusahaan adalah 0,6869 yang berada dibawah nilai rata-rata ukuran perusahaan yaitu 12,5965 memiliki arti bahwa variasi data sudah cukup tinggi dalam penelitian ini.

Variabel interaksi antara pengungkapan CSR dengan ukuran perusahaan $\left(\mathrm{X}_{1} \mathrm{Z}\right)$ memiliki nilai minimum sebesar 0,7158 dan nilai maksimum sebesar 7,8450. Nilai rata-rata sebesar 2,5462 dengan standar deviasi sebesar 1,5729 yang lebih kecil dari pada nilai rata-rata.

Selanjutnya dilakukan uji asumsi klasik, model persamaan regresi 1 berdistribusi normal karena memiliki nilai Kolmogorov Smirnov sebesar 0,093 dan Asymp. Sig (2-tailed) yaitu 0,200lebih besar dari 0,05. Nilai uji DurbinWatson sebesar 2,101. Nilai dU untuk jumlah sampel 63 dengan 1 variabel bebas (k) serta level of significant 5\% (0,05) adalah 1,6243. Maka nilai 4-dU adalah 2,3757, sehingga hasil uji autokolerasinya adalah $\mathrm{dU}<\mathrm{d}<(4-\mathrm{dU})$, yaitu $1,6243<$ $2,101<2,3757$. Hal ini berarti koefisien regresi bebas dari gangguan autokolerasi. nilai signifikansi untuk variabel Corporate Social Responsibility $\left(\mathrm{X}_{1}\right)$ sebesar 0,116, variabel ukuran perusahaan $(Z)$ sebesar 0,214, serta interaksi $\left(X_{1} Z\right)$ sebesar 0,099. Hal ini berarti nilai signifikansi masing-masing variabel serta interaksinya lebih besar dari 0,05 sehingga dapat disimpulkan bahwa model regresi bebas dari gejala heteroskedastisitas.

Uji Moderated Regression Analysis (MRA) yang merupakan suatu uji yang dilakukan untuk mengetahui apakah variabel ukuran perusahaan mampu 
mempengaruhi hubungan pengungkapan corporate social responsibility terhadap nilai perusahaan. Hasil pengujian disajikan pada Tabel 4 berikut ini.

Tabel 4.

Hasil Uji Moderated Regression Analysis

\begin{tabular}{cccccc}
\hline \multirow{2}{*}{ Model } & \multicolumn{2}{c}{$\begin{array}{c}\text { Unstandardized } \\
\text { Coefficients }\end{array}$} & $\begin{array}{c}\text { Standardized } \\
\text { Coefficients }\end{array}$ & \multirow{2}{*}{ T } & \multirow{2}{*}{ Sig. } \\
\cline { 2 - 4 } & $\mathbf{B}$ & Std. Error & Beta & & \\
\hline (Constant) & 3,538 & 1,886 & & 1,876 & 0,066 \\
Pengungkapan CSR $\left(\mathrm{X}_{1}\right)$ & $-21,928$ & 11,265 & $-7,632$ & $-1,947$ & 0,056 \\
Ukuran Perusahaan $(\mathrm{Z})$ & $-0,218$ & 0,147 & $-0,438$ & $-1,482$ & 0,144 \\
Interaksi $\left(\mathrm{X}_{1} \mathrm{Z}\right)$ & 1,782 & 0,870 & 8,202 & 2,049 & 0,045 \\
\hline Adjusted $R$ S Square & 0,214 & & & & \\
F & 6,632 & & & & \\
F Sig. & 0,001 & & & & \\
\hline
\end{tabular}

Sumber: Data diolah, 2018

Persamaan regresi yang dihasilkan melalui Moderated Regression Analysis adalah sebagai berikut:

$\mathrm{Y}=3,538-21,928 \mathrm{X}_{1}-0,218 \mathrm{Z}+1,782 \mathrm{X}_{1} \mathrm{Z}+e$

Berdasarkan Tabel 4 dapat dilihat nilai $\mathrm{F}$ hitung sebesar 6,632 dengan tingkat signifikansi sebesar $0,001<0,05$. Hasil tersebut menunjukkan bahwa variabel-variabel independen yaitu pengungkapan corporate social responsibility beserta interaksinya berpengaruh terhadap variabel dependennya yaitu nilai perusahaan. Berdasarkan hasil tersebut maka dapat disimpulkan bahwa model penelitian ini dikatakan layak untuk diteliti dan dapat dilanjutkan dengan pembuktian hipotesis.Hasil uji koefisien determinasi dapat dilihat pada Tabel 4. Berdasarkan Tabel 4 menunjukkan nilai koefisien determinasi sebesar 0,214 yang berarti $21,4 \%$ variasi nilai perusahaan dapat dijelaskan oleh variasi dari pengungkapanCSR, dan ukuran perusahaan, sedangkan sebesar 78,6\% dapat dijelaskan oleh variabel-variabel lain di luar model penelitian. 
Berdasarkan Tabel 4 variabel pengungkapan CSR yang diproksikan dengan Corporate Social Responsibility Index (CSRI), memiliki hasil koefisien pengungkapan CSR sebesar -21,928 dengan nilai p-value sebesar 0,056 > 0,05, sehingga menjelaskan bahwa pengungkapan CSR tidak berpengaruh pada nilai perusahaan. Hasil penelitian ini menunjukkan bahwa semakin besar pengungkapan corporate social responsibility yang dilakukan suatu perusahaan, maka nilai perusahaan menjadi semakin menurun. Hasil tersebut tidak mendukung teori sinyal, yang menyebutkan bahwa pengungkapan informasi CSR yang semakin luas akan memberikan sinyal positif terhadap investor, sehingga dapat meningkatkan nilai perusahaan karena nilai perusahaan dikatakan baik apabila harga saham perusahaan mengalami peningkatan. Hasil tersebut juga tidak mendukung teori legitimasi, yang menyebutkan bahwa dengan mengungkapkan aktivitasCSR, masyarakat akan memberi nilai positif terhadap perusahaan, karena perusahaan telah menunjukkan kepatuhannya terhadap norma-norma yang berlaku di masyarakat (Branco \& Rodrigues, 2008). Hasil penelitian ini menunjukkan bahwa besar kecilnya pengungkapan CSR tidak memengaruhi peningkatan nilai perusahaan, karena sebagian besar perusahaan publik hanya memfokuskan diri pada faktor keuangan, perusahaan kurang berfokus pada faktor non keuangan, sepertiCSR. Hal ini dapat dilihat dari rendahnya nilai pengungkapan CSR yang dilakukan perusahaan.

Hasil ini mendukung penelitian dari Pramana \& Mustanda (2016), Fauziah et al. (2016), Komalasari \& Purnawati (2017), serta Pribady et al. (2017), yang menyatakan bahwa pengungkapan CSR tidak berpengaruh terhadap nilai 
perusahaan. Hal tersebut dikarenakan dalam pengungkapan informasi CSR di setiap perusahaan memiliki perbedaan. Perbedaan tersebut disebabkan karena pelaporan pengungkapan CSR tidak memiliki standar yang baku dalam penyusunannya, sehingga terdapat banyak perusahaan yang terdaftar di Bursa Efek Indonesia memiliki pengungkapan corporate social responsibility yang rendah atau tidak secara rinci. Hasil ini juga mendukung hasil penelitian Pratama et al. (2016), yang menyatakan bahwa perusahaan dengan pengungkapan CSR yang tinggi akan berakibat pada tingginya beban yang harus dikeluarkan perusahaan untuk melakukan kegiatan CSR tersebut, sehingga akan berdampak pada berkurangnya laba yang diperoleh perusahaan dan akan berdampak pada penurunan nilai perusahaan.

Berdasarkan Tabel 4, variabel interaksi ukuran perusahaan dengan pengungkapan CSR $\left(\mathrm{X}_{1} \mathrm{Z}\right)$ memiliki nilai koefisien regresi sebesar 1,782 dengan nilai $p$-value sebesar $0,045<0,05$ maka $\mathrm{H}_{1}$ diterima, yang menjelaskan bahwa ukuran perusahaan mampu memoderasi hubungan pengungkapan CSR pada nilai perusahaan, dan hasil uji menunjukkan bahwa ukuran perusahaan memoderasi secara positif pengaruh pengungkapan CSR pada nilai perusahaan. Hasil penelitian ini menunjukkan bahwa semakin besar ukuran perusahaan, maka akan memperkuat pengaruh pengungkapan CSR pada nilai perusahaan. Artinya, perusahaan yang berukuran besar dapat mempengaruhi pengungkapan CSR, semakin besar perusahaan dan semakin banyak pengungkapan CSR perusahaan maka dapat meningkatkan nilai perusahaan. 
Hasil penelitian ini mendukung teori sinyal yang menyatakan bahwa bahwa pengungkapan informasi CSR yang semakin luas akan memberikan sinyal positif terhadap investor, sehingga dapat meningkatkan nilai perusahaan. Perusahaan besar cenderung mengungkapkan informasi CSR lebih luas untuk meningkatkan reputasinya di mata publik, sehingga hal tersebut dapat memberikan sinyal positif terhadap investor yang nantinya akan berdampak pada peningkatan nilai perusahaan. Pengungkapan CSR merupakan sebuah sinyal untuk mengungkapkan tambahan informasi kepada para stakeholder, khususnya pada negara berkembang (Su, Peng, Tan, \& Cheung, 2016). Hasil penelitian ini juga mendukung teori legitimasi yang menyatakan bahwa ukuran perusahaan yang besar akan mengungkapkan informasi tanggungjawab sosialnya lebih luas untuk mendapatkan legitimasi dari masyarakat, karena perusahaan besar melakukan aktvitasnya lebih banyak sehingga akan berdampak lebih besar pada lingkungan (Yuliawati \& Sukirman, 2015).

Hasil ini mendukung penelitian dari Putri et al. (2016), Wulandari \& Wiksuana (2017), Pratama \& Wiksuana (2016), serta Puspaningrum (2017), yang menyatakan bahwa ukuran perusahaan mampu memoderasi pengaruh CSR terhadap nilai perusahaan. Hal ini dikarenakan perusahaan yang dengan skala besar akan mengungkapkan informasi CSR lebih besar dibandingkan dengan perusahaan yang berukuran kecil. Dengan mengungkapkan kepedulian pada lingkungan melalui annual report, maka perusahaan dalam jangka waktu panjang bisa terhindar dari biaya yang sangat besar akibat dari tuntutan masyarakat. Perusahaan besar akan lebih mudah untuk mendapatkan suntikan dana dari para 
Luh Putri Wedayanti dan I Gde Ary Wirajaya.Pengaruh...

investor, dan dengan adanya dana tersebut, perusahaan diharapkan dapat mengelolanya dengan baik untuk mengembangkan usahanya maupun untuk melaksanakan kegiatan di luar perusahaan, yang nantinya dapat meningkatkan nilai perusahaan (Dewi, 2015).

Hasil penelitian ini menunjukkan bahwa bahwa pengungkapan CSR tidak memberikan pengaruh pada peningkatan nilai perusahaan. Hal ini berarti ketika pengungkapan CSRmemiliki nilai yang tinggi, maka dapat menurunkan nilai perusahaan. Hal ini terjadi karena adanya perbedaan persepsi antara perusahaan dan investor. Perusahaan berkeyakinan bahwa pada saat melaksanakan pengungkapan CSR sebanyak-banyaknya sebagai sinyal bahwa perusahaan memiliki kinerja finansial yang baik dan sudah memenuhi semua tanggung jawab perusahaan di bidang ekonomi, lingkungan, dan sosial dengan sangat baik, namun ternyata sinyal tersebut tidak dapat diterima dengan baik oleh investor. Investor menilai bahwa perusahaan tidak seharusnya melakukan pengungkapan CSR sebanyak-banyaknya, karena investor beranggapan bahwa kegiatan CSR yang dilakukan perusahaaan akanmemerlukan banyak biaya untuk merealisasikannya. Investor juga beranggapan bahwa CSR merupakan biaya bukan investasi jangka panjang bagi perusahaan, sehingga dapat menambah pengeluaran dan menurunkan profit perusahaan yang nantinya akan berimbas pada kemakmuran pemegang saham yang dapat menurun. Hal ini berarti pengungkapan CSR yang luas tidak dapat diterima sebagai sinyal positif, selain itu juga tidak dapat meningkatkan legitimasi masyarakat kepada perusahan untuk memperoleh keuntungan maksimal dari hasil berinvestasi. 
Ukuran perusahaan mampu memoderasi dengan memperkuat hubungan pengungkapan CSR pada nilai perusahaan. Sesuai dengan teori sinyal yang menyatakan bahwa pengungkapan CSR secara luas, dapat memberikan sinyal positif terhadap investor, sehingga dapat meningkatkan nilai perusahaan. Semakin besar ukuran perusahaan, maka perusahaan tersebut akan semakin luas untuk melaksanakan pengungkapanCSR, sehingga perusahaan tersebut akan memiliki image/ reputasi yang baik dimata para stakeholder terkait dengan kinerja dan tanggungjawab perusahaan terhadap ekonomi, lingkungan, dan sosial. Perusahaan yang melaksanakan pengungkapan CSR secara luas, juga akan mendapatkan legitimasi dari masyarakat, sesuai dengan teori legitimasi. Sinyal positif yang sudah diberikan perusahaan mampu diterima dengan baik oleh investor dan meningkatkan minat serta kepercayaan investor untuk berinvestasi dengan harga yang tinggi pada saham perusahaan, karena bagi investor perusahaan akan memberikan keuntungan secara sustainable, dan harga saham yang tinggi tersebut nantinya akan berdampak pada peningkatan nilai perusahaan. Hal ini berarti ukuran perusahaan yang besar, pengungkapan CSR yang luas, dapat diterima sebagai sinyal positif oleh investor dan dapat meningkatkan legitimasi masyarakat kepada perusahaan.

Hasil penelitian ini dapat dijadikan pertimbangan bagi perusahaan terutama bagi manajer untuk menentukan keputusannya dalam hal pengungkapan CSR. Hasil penelitian ini menunjukkan tingkat pengungkapan CSR perusahaan bernilai tinggi akan meningkatkan nilai perusahaan apabila perusahaan tersebut termasuk perusahaan besar. Oleh sebeb itu, perusahaan harus menyeimbangkan fokus 
terhadap peningkatan penjualan terlebih dahulu, sehingga dapat meningkatkan profit. Apabila profit perusahaan sudah meningkat, selanjutnya kegiatan CSR akan sesuai dengan rencana perusahaan untuk meningkatkan pelestarian lingkungan dan taraf hidup masyarakat sekitar.

\section{SIMPULAN}

Berdasarkan hasil analisis dan pembahasan yang telah diuraikan pada bab sebelumnya, maka didapatkan simpulkan bahwa ukuran Perusahaan mampu memoderasi dengan memperkuat antara variabel pengungkapan CSR pada nilai perusahaan. Artinya, semakin besar ukuran perusahaan, maka perusahaan tersebut akan semakin luas untuk melaksanakan pengungkapanCSR, sehingga perusahaan tersebut akan memiliki image/ reputasi yang baik dimata para stakeholder terkait dengan kinerja dan tanggungjawab perusahaan terhadap ekonomi, lingkungan, dan sosial, sehingga hal tersebut akan diikuti dengan peningkatan nilai perusahaan. Perusahaan besar dengan pengungkapan CSR yang luas juga akan mendapatkan legitimasi dari masyarakat serta memberikan sinyal positif terhadap para investor dan calon investor agar tidak ragu untuk menanamkan modalnya di perusahaan.

Bagi penelitian selanjutnya agar dapat mengkaji dan menyempurnakan model penelitian ini, mengingat koefisien determinasi $\left(\mathrm{R}^{2}\right)$ yang rendah dalam penelitian ini, yakni sebesar $21,4 \%$. Artinya $78,6 \%$ dari variasi nilai perusahaan dapat dijelaskan oleh variabel-variabel lain di luar model penelitian. Peneliti juga menyarankan agar dapat memilih lokasi penelitian selain perusahaan pertambangan yang terdaftar di BEI guna melihat pengaruh variabel bebas lainnya 
terhadap nilai perusahaan. Disarankan agar dapat menggunakan pengukuran yang lainnya seperti Price Earning Ratio (PER) untuk proksi nilai perusahaan dan Ln (Total Aset) untuk proksi ukuran perusahaan.

\section{REFERENSI}

Anggraini, F. R. R. (2006). Pengungkapan Informasi Sosial dan Faktor-Faktor yang Mempengaruhi Pengungkapan Informasi Sosial dalam Laporan Keuangan Tahunan ( Studi Empiris pada Perusahaan-Perusahaan yang terdaftar Bursa Efek Jakarta ). Simposium Nasional Akuntansi 9 Padang, 2326.

Branco, M. C., \& Rodrigues, L. L. (2008). Factors influencing social responsibility disclosure by Portuguese companies. Journal of Business Ethics, 83(4), 685-701. https://doi.org/10.1007/s10551-007-9658-Z

Budi, T. S. W., \& Djazuli, A. (2013). Pengaruh Pengungkapan Corporate Social Responsibility Dan Kinerja Keuangan Perusahaan Terhadap Return Saham Perusahaan di Indeks LQ45 Bursa Efek Indonesia. Jurnal Ilmiah Mahasiswa FEB Universitas Brawijaya, 1(2).

Bulan, A. A. A. T., \& Astika, I. B. P. (2014). Moderasi Corporate Social Responsibility terhadap Pengaruh Kinerja Keuangan pada Nilai Perusahaan. E-Journal Akuntansi Universitas Udayana, 8(2), 136-151.

Dewi, K., \& Monalisa. (2016). Effect of Corporate Social Responsibility Disclosure on Financial Performance with Audit Quality as a Moderating Variable. Binus Business Review, 7(2), 149-155.

Dewi, R. R. (2015). Pengaruh Pengungkapan Corporate Social Responsibility, Ukuran Perusahaan, Leverage, dan Dividen Payout Ratio Terhadap Nilai Perusahaan dengan Profitabilitas dan Kepemilikan Manajerial sebagai Variabel Moderasi (Studi Empiris pada Perusahaan Non-Keuangan y. Thesis Universitas Muhammadiyas Yogyakarta.

Fauziah, G., Irwanto, A. K., \& Syamsun, M. (2016). Pengaruh Pengungkapan Corporate Social Responsibility terhadap Nilai Perusahaan pada Indeks Saham LQ45. Jurnal Manajemen IKM, Institut Pertanian Bogor, 11(1), 5260. http://journal.ipb.ac.id/index.php/jurnalmpi/

Hackston, D., \& Milne, M. J. (1996). Some Determinants of Social and Environmental Disclosures in New Zealand Companies. Accounting, Auditing \& Accountability Journal, 9(1), 77-108. https://doi.org/10.1108/09513579610109987

Haniffa, R., \& Cooke, T. E. (2005). The impact of culture and governance on corporate social reporting. Journal of Accounting \& Public Policy, 24(5), 
$391-430$.

Haruman, T. (2008). Pengaruh Struktur Kepemilikan terhadap Keputusan Pendanaan (Perspektif Agency Theory). Simposium Nasional Akuntansi XI, Pontianak.

Ilmi, M., Kustono, A. S., \& Sayekti, Y. (2017). Effect of Good Corporate Governance, Corporate Social Responsibility Disclosure and Managerial Ownership To the Corporate Value With Financial Performance As Intervening Variables: Case on Indonesia Stock Exchange. International Journal of Social Science and Business, 1(2), 75-88.

Komalasari, D., \& Purnawati, N. K. (2017). Peran Profitabilitas dalam Memoderasi Pengaruh Corporate Social Responsibility Terhadap Nilai Perusahaan. Prosiding Seminar Nasional AIMI, 12(1), 27-28.

Kusumawardani, I., \& Sudana, I. P. (2017). Faktor-Faktor yang Mempengaruhi Pengungkapan Corporate Social Responsibility. E-Journal Akuntansi Universitas Udayana, 19(1), 741-770.

Kusumayani, H. A., \& Suardana, K. A. (2017). Kepemilikan Manajerial dan Kepemilikan Institusional Sebagai Pemoderasi Pengaruh Perencanaan Pajak Pada Nilai Perusahaan. E-Jurnal Akuntansi Universitas Udayana, 18(1), 646-673.

Lesmana, I. P. A. S., \& Sukartha, I. M. (2017). Pengaruh Manajemen Laba pada Nilai Perusahaan Manufaktur yang Terdaftar di Bursa Efek Indonesia Tahun 2012-2015. E-Jurnal Akuntansi Universitas Udayana, 19(2), 1060-1087.

Listiyorini, Eko. 2007. Menghitung Kerugian Bencana Lumpur Lapindo. https://www.antaranews.com/berita/60003/menghitung-kerugian-bencanalumpur-lapindo. Diakses 27 Desember 2017.

Medyawati, H., \& Yunanto, M. (2017). The Influence of Corporate Social Responsibility to the Value Of Company in Indonesia. International Journal Globalisation and Small Business, 9(1), 54-60.

Mukhtaruddin, Relasari, \& Felmania, M. (2014). Good Corporate Governance Mechanism , Corporate Social Responsibility Disclosure on Firm Value: Empirical Study on Listed Company in Indonesia Stock Exchange. International Journal of Finance \& Accounting Studies, 2(1), 1-10. https://doi.org/10.7575/aiac.ijfas.v.2n.1p.1

Mule, R. K., Mukras, M. S., \& Nzioka, O. M. (2015). Corporate Size, Profitability and Market Value: an Econometric Panel Analysis of Listed Firms in Kenya. European Scientific Journal, 11(13), 376-396.

Nguyen, B. T. N., Tran, H. T. T., Le, O. H., Nguyen, P. T., Trinh, T. H., \& Le, V. (2015). Association between Corporate Social Responsibility Disclosures and Firm Value - Empirical Evidence from Vietnam. International Journal of Accounting and Financial Reporting, 5(1), 212-228. 
Pramana, I. G. N. A. D., \& Mustanda, I. K. (2016). Pengaruh Profitabilitas dan Size terhadap Nilai Perusahaan dengan CSR sebagai Variabel Pemoderasi. EJurnal Manajemen Unud, 5(1), 561-594. https://doi.org/ISSN : 2302-8912

Prasetyorini, B. F. (2013). Pengaruh Ukuran Perusahaan, Leverage, Price Earning Ratio, dan Profitabilitas terhadap Nilai Perusahaan. Jurnal Ilmu Manajemen, 1(1), 183-196.

Pratama, G. L., Hapsari, D. W., \& Muslih, M. (2016). Pengaruh Corporate Social Responsibility Terhadap Nilai Perusahaan dengan Profitabilitas sebagai Variabel Pemoderasi. E-Proceeding of Management, Universitas Telkom, 3(3), 3432-3438.

Pratama, I. G. B. A., \& Wiksuana, I. G. B. (2016). Pengaruh Ukuran Perusahaan dan Leverage terhadap Nilai Perusahaan dengan Profitabilitas sebagai Variabel Mediasi. Jurnal Manajemen Universitas Udayana, 5(2), 13381367.

Prayogo, D. (2013). Measuring Corporate Social Responsibility for Local Communities in Mining, Oil and Gas Industries, The Case of Indonesia. Journal of Economics and Sustainable Development, 4(1), 59-69.

Pribady, N., Rakhman, A., \& Bunfa, L. (2017). Pengaruh Pengungkapan Corporate Social Responsibility Terhadap Nilai Perusahaan dengan Profitabilitas Sebagai Variabel Moderating pada Perusahaan Manufaktur di BEI. Jurnal Manajemen Keuangan, 24(1), 1-11.

Primady, G. R., \& Wahyudi, S. (2015). Pengaruh Corporate Social Responsibility dan Profitabilitas Terhadap Nilai Perusahaan Dengan Kepemilikan Manajerial Sebagai Variabel Pemoderasi. Diponegoro Journal Of Management, 4(3), 1-15. Retrieved from http://ejournals1.undip.ac.id/index.php.dbr

Purwanto, A. (2011). Pengaruh Tipe Industri, Ukuran Perusahaan, Profitabilitas, Terhadap Corporate Social Responsiblity. Jurnal Akuntansi Dan Auditing, 8(1), 12-29. https://doi.org/10.14710/jaa.v8i1.4344

Puspaningrum, Y. (2017). Pengaruh Corporate Social Responsibility dan Kepemilikan Manajerial Terhadap Nilai Perusahaan dengan Profitabilitas dan Ukuran Perusahaan sebagai Variabel Moderating. Jurnal Profita, 2(1), 1-14.

Putri, A. K., Sudarma, M., \& Purnomosidhi, B. (2016). Pengaruh Corporate Social Responsibility terhadap Nilai Perusahaan dengan Ukuran Perusahaan dan Jumlah Dewan Komisaris sebagai Variabel Pemoderasi (Studi pada Perusahaan Manufaktur yang terdaftar Bursa Efek Indonesia). Jurnal Aplikasi Manajemen, 14(2), 344-358.

Putri, I. A. S., \& Suprasto, B. (2016). Pengaruh Tanggungjawab Sosial Perusahaan dan Mekanisme Tata Kelola Perusahaan terhadap Nilai Perusahaan. E-Journal Akuntansi Universitas Udayana, 15(1), 667-694. 
Qomariah, N. (2015). The Effect of Corporate Social Responsibility, Size, and Profitability Toward On the Value of Corporate. Journal of Business and Management, 17(2), 25-30. https://doi.org/10.9790/487X-17212530

Rinnaya, I. Y., Andini, R., \& Abrar, O. (2016). Pengaruh Profitabilitas, Rasio Aktivitas, Keputusan Pendanaan, Keputusan Investasi terhadap Nilai Perusahaan (Studi Empiris Pada Perusahaan Manufaktur Yang Terdaftar Di BEI Tahun 2010-2014). Journal Of Accounting, 2(2), 1-18.

Rustiarini, N. I. W. (2010). Pengaruh Corporate Governance Pada Hubungan CSR dan Nilai Perusahaan. Simposium Nasional Akuntansi XIII, 1-24.

Setiadharma, \& Machali, M. (2017). The Effect of Asset Structure and Firm Size on Firm Value with Capital Structure as Intervening Variable. Journal of Business \& Financial Affairs, 6(4), 1-5. https://doi.org/10.4172/21670234.1000298

Sholekah, F. W., \& Venusita, L. (2014). Pengaruh Kepemilikan Manajerial, Kepemilikan Institusional, Leverage, Firm Size, dan Corporate Social Responsibility terhadap Nilai Perusahaan Pada Perusahaan High Profile yang Terdaftar di Bursa Efek Indonesia Periode 2008-2012. Jurnal Ilmu Manajemen, 2(3), 795-807.

Silalahi, A. C., \& Ardini, L. (2017). Pengaruh Pengungkapan Corporate Social Responsibility , Leverage dan Ukuran Perusahaan Terhadap Kinerja Keuangan. Jurnal Ilmu Dan Riset Akuntanbsi, 6(8), 1-18.

Subiantoro, O. H., \& Mildawati, T. (2015). Pengaruh Karakteristik Perusahaan terhadap Pengungkapan Corporate Social Responsibility. Jurnal Ilmu \& Riset Akuntansi, 4(9), 1-11.

Suchman, M. C. (1995). Managing Legitimacy: Strategic and Institutional Approaches. Academy of Management Review, 20(3), 571-610. https://doi.org/10.5465/AMR.1995.9508080331

Suciati, \& Rahayu, Y. (2017). Pengaruh Ukuran Perusahaan, Kebijakan Hutang dan Profitabilitas Terhadap Nilai Perusahaan. Jurnal Ilmu Dan Riset Akuntansi, 6(5), 1-20.

Sugiyono. (2014). Metode Penelitian Pendidikan Pendekatan Kuantitatif. Kuantitatif dan $R \& D$. Bandung: Alfabeta.

Suryonugroho, B. (2016). Pengaruh Corporate Social Responsibility (CSR) Terhadap Nilai Perusahaan. Jurnal Profita, 2(2), 1-21.

Susanti, F., Marietza, F., \& Indriani, R. (2012). The Influences of Corporate Social Responsibility to Firm Value with Profitability and Leverage as Moderating Variable. PROCEEDING The 13th Malaysia Indonesia Conference on Economics, Management and Accounting (MICEMA), 360373. 
Umbara, D. M. B., \& Suryanawa, I. K. (2014). Pengaruh Pengungkapan Tanggung Jawab Sosial Pada Nilai Perusahaan. E-Jurnal Akuntansi Universitas Udayana 9.2, 9(2), 410-424.

Wiagustini, Ni Luh Putu. (2014). Manajemen Keuangan. Denpasar: Udayana University Press.

Wiguna, I. P. I., \& Putri, I. G. A. M. A. D. (2016). Voluntary Disclosure Sebagai Pemoderasi Pengaruh Good Corporate Governance Terhadap Nilai Perusahaan. E-Jurnal Akuntansi Universitas Udayana, 17(3), 1700-1726.

Wulandari, N. M. I., \& Wiksuana, I. G. B. (2017). Peranan Corporate Social Responsibility dalam Memoderasi Pengaruh Provitabilitas, Leverage, dan Ukuran Perusahaan terhadap Nilai Perusahaan. E-Jurnal Manajemen, 6(3), $1278-1311$.

Yuliawati, R., \& Sukirman. (2015). Faktor-Faktor yang Mempengaruhi Pengungkapan Corporate Social Responsibility. Accounting Analysis Journal, 4(4), 1-9. https://doi.org/ISSN 2252-6765 